\title{
The Role of Network Quality as Moderating Variable on the Performance Enhancement of Islamic Microfinance Institutions (Cases of Baitul Mal Wat Tamwil)
}

\author{
Muhamad Mutaqin \\ BMT Inti Muamalat, Bandungan Semarang Regency, \\ Central Java, Indonesia. \\ E-mail: mtqn70@gmail.com \\ Widiyanto bin Mislan Cokrohadisumarto \\ (Corresponding Author) \\ Department of Management,, Faculty of Economics \\ Sultan Agung Islamic University, Semarang, \\ Central Java, Indonesia.
}

E-mail: widiyantopunt@hotmail.com and familiar@unisula.ac.id.

\begin{abstract}
Islamic microfinance institutions (IMFI) - such as Baitul Mal Wat Tamwil (BMT) - have an important role in developing the micro-enterprises in Indonesia. Therefore, the performance improvement of BMT institutions should be carried out continuously in order to enhance its role in contributing to the development of the national economy, namely through the development of micro enterprises. The purpose of this study is to develop an improvement of the BMT performance model by involving the variables of human capital, Islamic business ethics, and moderation variable of network quality. The results of the study showed that the human capital and Islamic business ethics have a significant effect on the BMT performance, and the network quality is able to strengthen the
\end{abstract}


Keywords:

Human capital, Islamic business ethics, network quality, BMT Performance effect of human capital and Islamic business ethics in improving the BMT performance. This result indicates that the network quality as moderation variable has an important role in improving the BMT performance.

\section{INTRODUCTION}

The existence of Islamic microfinance institutions in Indonesia (with sharia cooperative legal entities) has spread to almost all parts of Indonesia in the form of Baitul Maal wat Tamwil (BMT). BMT is a microfinance institution that operates by using two functions, namely the Baitul Maal and baitul tamwil. The existence of shariacooperatives (such as BMT) offers an alternative financial system for Muslims who need or wish to obtain financial services without violating the prohibition of usury. The existence of BMT is expected to help resolve the national issue namely eradicating poverty. In order to be as expected, BMT required to having good performance in achieving objectives. According to Kaplan (1996), companies performance become the measurement of success, and therefore, we need a method to measure such performance. Surely, this can also be applied to measure the BMT performance. The performance measurement aims to enable companies to compare the current and previous year of performance achievement, or to compare the performance of its main competitors. By knowing the condition of business performance, the company can do a revision of policies that are not relevant, so that the next organizational performance achievement will be better. Many factors can affect the organizational/company performance, including the factor of human capital. Mayo (2000) revealed that human capital is the core of a company, and it has five components, namely individual capability, individual motivation, leadership, the organizational climate, and workgroup effectiveness. Each component has different roles in creating human capital of companies that will ultimately determine the corporate value. This shows that human capital is an important factor that needs to be addressed more seriously. Nzuve and Bundi (2014) expressed human 
capital will enhance the company's performance. Although there are studies that show different results such as Olayemi (2012), he showed that human capital does not significantly affect the company's performance. The difference results of this study can be a starting point to conduct further research.

Currently, business ethics were also highlighted as essential by many parties including business experts, especially among Muslims. Islam does not allow people to work as they pleased such as achieving the goals and desires by justifying any ways such as deception, fraud, perjury, usury, bribery and so forth. Islam provides a boundary between who should and who should not, right and wrong as well as the lawful and the unlawful. Restriction or dividing line is known as ethical (moral). Behavior in business or trade is also not spared from their moral values or business ethics values. It is important for businesses to integrate moral dimension into the framework/business scope. Islam provides a duty for every Muslim to implement the Islamic law in all aspects of life including muamalah (business) rules, which become the way of survive in life. In essence, the purpose of applying the rules (Sharia) in the Islamic knowledge, in the field of muamalah, the particular conduct of business is for creating blessings and noble revenue, so it will create human development with justice and stabilization to achieve fulfillment, full employment and income distribution is uneven without must undergo a prolonged imbalance in society (Eldine, 2009).

Another important factor that can affect the performance of the business is networking. Kalm (2012) found that increasing activity with network actors is positively connected with firm performance (i.e., firm growth as measured in both revenue and employment growth). In line with these findings related to the development of the activity of BMT, networking plays an important role. For example, as stated by Widiyanto (2012), the BMT asset growth in areas that have networking (i.e. BMT association) faster than that do not have a BMT network.

In reality, in the last few years, it shows that BMT has developed very rapidly. The development of BMT in Central Java until 2012 experienced a significant increase compared to 2011. This can be seen from the number of BMT Central Java assets 
increased to $47 \%$ because in 2011 the BMT Central Java assets as many as 1.8 trillion and in 2012 the number of assets was 3.4 trillion. In 2013, the amount of the assets of BMT in Central Java has reached 6.4 trillion with the number of Human Resources as many as 3977 people (Data of Korwil PBMTI Central Java). According to Sumiyanto (2012), there are so many BMT that is not accompanied by the supporting factors which enable BMT to continue to develop and run well. There is a lot of evidence shows that there are many of them who no longer operate BMT (disbanded) for various reasons such as; management is not good; the human resources are not trustworthy, HR professionals who are less able to work, cannot attract people's trust, the difficulty of capital and so on. As a result, the image of BMT in some communities is very bad, BMT is known as bad institutions, untrustworthy, not sharia-compliant, only selling sharia issue, and so forth.

The figures above show that the overall BMT performance still needs to be improved so as to meet the social demands. Therefore, this paper aims to develop a performance improvement model in Islamic microfinance institutions (i.e. BMT) based on human capital, Islamic business ethics and network quality (as a moderating variable). This paper consists of five parts. The first part is the introduction. The second part is a literature review and the third part is a methodology, the forth part is the results and discussion. The fifth part contains of conclusions, policy implementation and limitations of the study.

\section{LITERATURE REVIEW}

\section{Company Performance (BMT)}

Company Performance (BMT)

To be successful and competitive the company needs to pay greater attention on its business performance, and according to Al-Matari, et al (2014) organizational (company) performance requires measures to identify the effect of organizational recourses upon business. The company's performance is defined as a feat the company which is measured in performance outcomes (Kaplan and Norton (1996). Furthermore, Rylková (2015) explained that performance is the entity's ability to achieve certain results comparable, on the basis of certain given 
criteria for a certain period of time. Besides this explanation, he also suggested how to measure performance, that performance measurement should include five main dimensions, namely: financial, market and customer, process, staff development and standards for the future. While Santos, et al (2012) measured company performancebased on fivedimensions, namely financial performance, customer satisfaction, employee satisfaction, social performance and environmental performance. According to (Pratono and Mahmood (2014), in essence the measure of performance can vary, depending on the type of industry.

The prior discussion shows that the measurement of company performance is more directed to the use of material measures. Performance measurement of Islamic financial institutions is certainly not enough to use material indicators only, because it has a different mission and objectives, which are consistent with the objectives of sharia. According Noruzi (2011) syariah goal is to improve a better life to all mankind. There are five objectives that must be passed, including protection toward faith or religion (din), soul (nafsi), intellect ('aql), lineage and honors (nashli), and property (maal). Those five sharia goals can be achieved with great effort by the human being as a whole. In the sharia objective, the protection of faith (religion) placed first, as it will provide a worldview that the tendency to affect the personality of the whole human being, behavior, lifestyle, tastes, preferences, and attitudes towards other human beings, resources, and environment. Religion will provide a balance between the interests of the material and the spiritual. Besides that, it becomes also a moral filter where people can use resources more valuable. Therefore, Islamic financial institutions must have a different performance indicator. Performance measurement in Islam is very concerned about worldly interests (material), spiritual interests and Hereafter interests (which is essential), individual interests and the social interests. Rafiki, et al (2014) suggested that humans function as caliph fil ard should fulfill their duty according to who gave the mandate, which is to manage the earth responsibly. That is responsible for the Creator and the welfare of the surrounding community. Rafiki, et al (2014) also stated that the welfare in Islam is; (i). Welfare holistic balanced, which includes material and spiritual dimensions as 
well as covers both individual and social. Human figure consists of physical and mental, hence happiness must be balanced between them. Similarly, humans have individual dimensions, but cannot be separated from the social environment. Humans would be happy if there is a balance among them with the social environment. (ii). Prosperity in the world and hereafter, because humans do not just live in the natural world but also hereafter. If this ideal cannot be achieved then the welfare of the Hereafter is certainly an advantage, because it becomes the more valuable in life (in all respects).

Relating to the measurement of BMT performance, it is important to take into consideration the objectives of the organization (as a reference performance measurement), which may different from the objectives of other business. Therefore, the BMT performance is a reflection of the BMT work achievements within a certain time, which as a financial institution that has a social mission (Baitul Maal) and as a financial institution that has the business or commercial (baitut tamwil) mission. Thus, BMT performance indicator is not a single character that can include: earnings growth, asset growth, the customer or member growth, Non Performing Financing (NPF), Zakat Management, donation, and sadaqah, and social roles. The next section will discuss several factors that influence BMT performance, including those related to human capital, business ethics, and network quality.

\section{Human Capital}

According to Martina, et al (2008), human capital can be defined as the economic value of human resources associated with the skills, knowledge, ideas, innovation, energy and commitment. Human capital is a combination of knowledge, skills, innovation and the ability to carry out their duties so as to create a value to achieve the goal. The added value formation is contributed by humancapital to perform tasks and jobs that would provide sustainable revenue in the future for an organization. Furthermore, Martina, et al (2008) stated that human capital reflects the company's collective ability to produce the best solution based on the knowledge possessed by the people in the company, and its achievement will be better if the company is able to use the knowledge held by employees. Nzuve and Bundi 
(2014) described human capital as a combination of three factors, namely: (i) the character or nature that is brought to the job, for example: intelligence, energy, positive attitude, reliability, and commitment, (ii) a person's ability to learn, namely intelligence, imagination, creativity and talent, and (iii) the motivation to share information and knowledge, the team spirit and goal orientation. Then, it is showed that human capital will enhance the company's performance. The results of a study conducted by Martina, et al (2008) showed individual capability and the organizational climate (as a component of human capital) have a significant effect on the company performance. Samad (2013) found that all of the human capital aspects were positively related to business performance and significantly it had a positive impact on business performance. Marimuthu, et al (2009) stated that there are reasonably strong evidence to show that the infusion of 'human capital enhancement' in organizations promotes the greater innovativeness and company performance. He also stated that financial performance is positively impacted through the consideration of human capitals. It means companies should come up with some effective plans investing especially in the various aspects of human capital in order to attain the greater company performance and also to ensure the company to remain competitive for their long term survival. Some other research results have also proven that human capital has an important influence (has a positive impact) on company performance [ (Tessema, 2014); (Urban \& Kongo, 2015); (Muafi, et al, 2017) ].

\section{Islamic Business Ethics}

Etymologically, ethics comes from the Greek word, that is 'ethos' which means an attitude, a way of thinking, habits, customs, morals, feelings and character of decency. Ethical terms have been used by Aristotle and the Greek philosopher to show moral philosophy. So, ethics means the principles, norms and standards that govern the behavior of individuals and groups who distinguish what is right and wrong. Business ethics seeks to prohibit business behavior, corporate managers and workers to do anything that they should not do. Business ethics as a code of moral principles and values direct behavior of an individual or a group in terms of what is right or wrong. These are established 
standards used to judge the rightness or wrongness of a business relative to others (Gbandi and Oseyomon, 2014). Business ethics affect how companies relate to the workers, how workers are associated with the company and how the company is dealing with agents or other economic actors (Eldine, 2009). According to Jalil (2010), etymologically, ethics show the individual basic character to do good things, social rules that restrict a person to do right or wrong, it is also known as the morality. Ethics is part of the philosophy that discuss rationally and critically about values, norms or morality. Terminology that is closest to the understanding of ethics in Islam is character/akhlaq (plural: khuluq). Ethics directs man towards the actualization of their best capacity. Application of ethics and honesty in business will increase the business entity value itself. With the higher level of competition and consumers are increasingly critical, so if customer satisfaction is maintained, it will lead to sustainable and trustworthy company in the long term (Nawatmi, 2010).

Companies that implement ethics would increase the motivation of workers, because work is required not only to a better result, but also must be done in a good way. The application of business ethics also protect the principles of free enterprise and enhance the competitive advantage, as well as prevent exposure to government sanctions for violating ethics that can be classified as a tort. Without business ethics, the company will go out of control, use a variety of ways, sacrifice anything to achieve the goal (Eldine, 2009).

Business ethics is also related to brand value. Ethical business behavior contributed to the company's image. The trick can be done by providing training to workers on ethics, the results were remarkable, for example, reduced cost, reduced violations and the destruction of the brand or reputation, and ultimately reduce the penalty or punishment for violating the rules set (Nawatmi, 2010). According Ferell, et al (2015) concerning business ethics organizational principles, values, and norms, which come from individuals, statement of the organization, or of a legal system that primarily drive the behavior of individuals and groups in carrying out the business. He noted that apply to business ethics in the company is very helpful, such as, it may increase the commitment of human resources, contribute to 
the loyalty of investors and customer satisfaction, which it will increase the company profit (as a form of corporate performance in finance).

Business ethics in Islam are a number of ethical business behavior (akhlaq al Islamiyah) wrapped in Islamic values that promote lawful (halal) and unlawful (haram). So that ethical behavior is behavior that following God's command and avoid from the ban. Islamic business ethics has been often discussed in the literature and is the main source of the Quran and Sunnah. Business people are expected to act ethically in its various activities. Trust, fairness and honesty are essential elements in achieving the success of the business in the future. Business is influenced not only by economic circumstances, but also by changes in social, political, economic and technological as well as shifts in attitudes and the stakeholders views (Kayed and Hasan, 2010).

Business in Islam is basically same as the general business, only to be submissive and obedient on the basis of the theory of the Qur'an, Sunnah, Al-Ijma and Qiyas (Ijtihad) as well as the limitations contained in these sources. There are several verses in the Qur'an that state about the business, including: AlBaqarah (275 and 282); An-Nisaa (29); At-Tauba (24); An-Nur (37); Fatir (29); As-Shaff (10) and Al-Jum'ah (11). Islam gives freedom to its adherents to do business, but in Islam there are some basic principles that became normative ethics that must be observed when a Muslim will and run a business, including: (i) The process of seeking sustenance for a Muslim is a mandatory duty, (ii) Sustenance was sought to be lawful (halal), (iii) The prohibition of usury, (iv) Do on consensual, (v) Be honest in running the business, (vi) All processes are done in the search for sustenance should be used as a means to draw closer to Allah SWT, (vii) Businesses that will be and are being implemented do not affect the environmental damage, (viii) Competition in business is used as a means for achieving fair and healthy (fastabikul al-khayrat), ix) Imbued with a mutual aid attitude.

Based on the description above, it can be identified that Islamic business ethics indicators are: the emphasis on the practice of mutual blessing or willing / no compulsion ( 'an 
taradhin), committing the lawful and good (halalan thayyiban), do not do speculation (maysir), free of act of manipulation (ghoror), free from the practice of usury, help to those who need ( $t a^{\prime} a w u n$ ), and have a social responsibility. Su (2014) stated that the application of business ethics in touch with all the components of intellectual capital, organizational capital, social capital and human capital. Ethical approach in business can spur employees to communicate openly, share knowledge, and help each other in solving the problem in order to improve organizational capital. Ethical approach can also strengthen the relationship among suppliers, customers, and other stakeholders to increase social capital. In addition, the ethical approach also maintains and develops the skills of employees so that human capital increases. According to Krishna, et al (2011), the implementation of well formulated ethical business policy has many benefits. Hitta \& Collins ( 2007), and also Kenneth \& Chukwuma (2015) showed that business ethics be able to improve the overall the company's performance in their operations. Specific for Islamic business ethics, Jaleleddine, et al (2014) showed that the Islamic business ethics will improve the company's performance in the presence of a strong network. Based on the description above, there will be a greater chance that the Islamic business ethics implementation in microfinance institutions (such as BMT) will affect the financial institutions performance.

\section{Network Quality}

According to Indonesian Dictionary, quality means the level of merits of something; levels; the degree or extent. Meanwhile Ranjay (n.d.) the organizational network as a group of organizations that care each other, where there is a close relationship among the members of the organization because of their common interest or values. Thus, the quality of the organizational network can be defined as the degree or level of care of organization group one another in relationships or are related because of their common interest or values. The process of formation of horizontal networks is done by organizations whose position is similar. The members within an organizational network has three important characteristics (Ranjay, n.d.), namely; (i) Sympathetic, so that the organization 
incorporated within calls as a "network of our organization".(ii) shared responsibility, where each organization are aware of the role in the organization and the state of the organization itself enables the role in the group that is being run, (iii) Mutual need, individuals who are as members of an organization feels that himself depend on the organizational network.

In organizational development, business networks have an important role. Research of Kariv, et al (2009) showed that there is a significant role of business networks in the measurement of business performance, particularly in sales and survival. Ranjay (n.d.) states that an organization is a member of a network (which is linear), then the organization will have improved performance, this is because more information and partnership working which is owned rather than organizations that are not members of a network. In the context of the BMT development, the network also has an important role. As revealed by Widiyanto (2012), the BMT asset growth in areas that have a network or association to grow faster than the regions that do not have an association. This was due to the petrified association members in solving problems of management, finance, and issues relating to Shariah. Network quality indicators are: mutual aid, mutual learning, and commitment to move forward together and remind each other.

Nzuve and Bundi (2014) showed that human capital would boost the company's performance in the presence of a strong network. Ranjay (n.d.) stated that an organization is a member of a linear network that has improved performance, this is because more information and cooperation rather than laborowned companies that do not follow an organizational network. Organizational network is able to stimulate human resources to have better human capital, and networks for organizations to make human resources more competitive, which means that the network quality is able to strengthen the influence of human capital on the organizational performance. Furthermore, Kalm (2012) demonstrated a positive connection between networking (the creation of new active relationships) and company growth. Maina, et al (2016) also found that networking (structure, governance and content) is vital for enhanced company performance. The prior discussion indicates 
that networking have an important role on the improvement of company performance.

Based on the discussion above, the hypothesis is formulated as follows:

H1: Human capital positively affects the BMT performance

$\mathrm{H} 2$ : Islamic Business ethics have a positive effect on the BMT performance

H3: Network quality strengthens the effect of human capital on the BMT performance

H4: Network quality strengthens the influence of Islamic Business Ethics on the BMT performance

With the BMT performance improvement model as shown below:

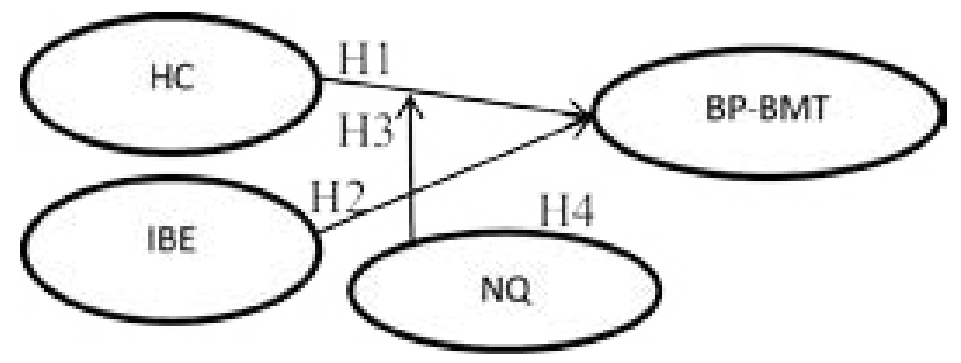

Figure 1. the BMT Performance Improvement Model

Note:

IBE: Islamic Business Ethics (Indicator: Mutual volunteer / noncoercive ('an taradhin), halalan thayyiban, not speculation (maysir), free from manipulation (ghoror), free of usury, help the weak, social responsibility.

NQ: Network Quality (Indicators: help each other, learn from each other, commitment to move forward together, tell each other).

HC:Human Capital (Indicators: Individual capability, Individual motivation, Leadership, Organizational climate, and Workgroup effectiveness).

BP -BMT: Business Performance of BMT (indicators: profit growth, asset growth, customer / member growth, 
reduction in Non Performing Financing, improved Zakat management, Infak and sadaqah, the social growth (through financing qardhul hasan).

\section{RESEARCH METHOD}

This research was conducted by census method by distributing questionnaires to $42 \mathrm{BMT}$ leaders who is a member PBMTI in Semarang. Likert scale of 1 (strongly disagree) - 5 (strongly agree) was used to measure each indicator of the variables studied. The purposes of analysis, validity and reliability of research instrument have been done. To test the influence among variables is done by using multiple regression analysis is preceded by a stage classic assumption test including normality test, multicollinearity test, heteroscedasticity test, and autocorrelation test with the results meet the requirements of these assumptions. The regression equation was formulated as follows:

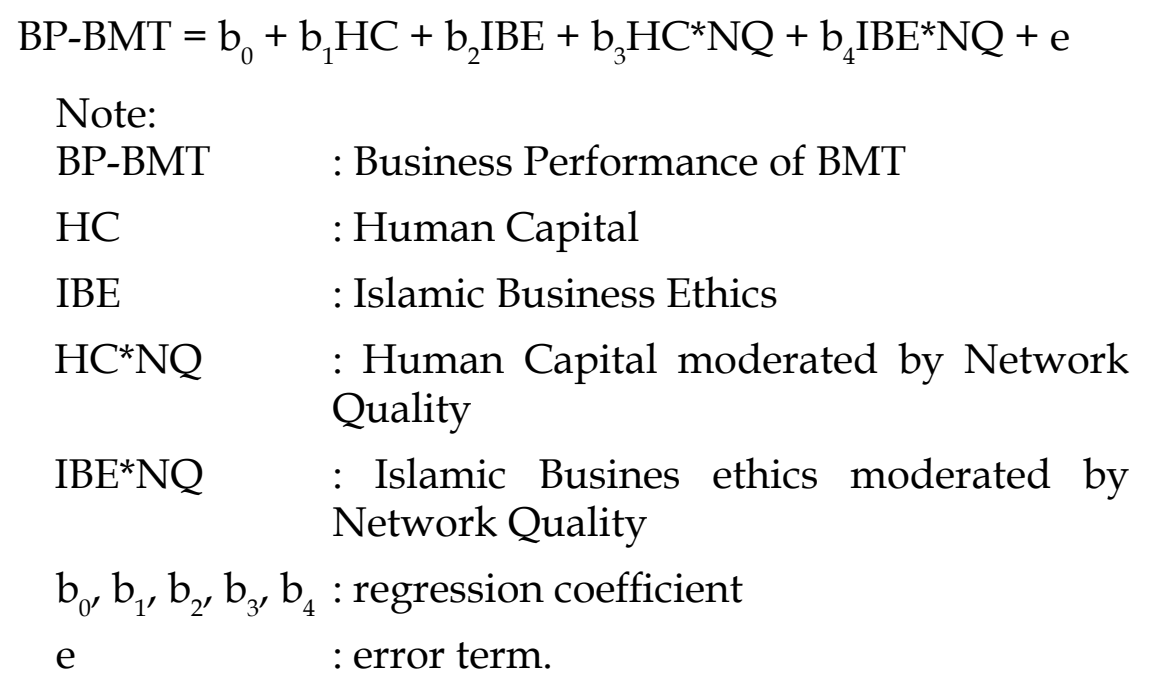

\section{RESULTS AND DISCUSSION BMT Overview}

BMT in Semarang are spread evenly in six areas; Semarang City, Semarang District, Salatiga City, Kendal District, Demak District, and Grobogan District. As a general description, BMT in Semarang has been established starting on 1993, this is the oldest BMT in Semarang which is currently 25 
years old. The research sample of the youngest BMT has been established in 2012. In general, BMT in this region has been aged more than 17 years; with the level of leadership education is a Diploma (D3) to Doctoral (S3) with the majority is Bachelor (S1). Based on assets held over the last five years, BMT assets grow around 30 percent to 50 percent. While the members growth ranged from 5 percent to 25 percent. This information at a glance illustrates that the BMT in Semarang experienced an encouraging growth.

\section{Variable Description}

\section{Human Capital}

Human Capital is evaluated based on the five indicators, namely; individual capability, individual motivation, leadership, organizational climate, and workgroup effectiveness. Based on survey results, it indicates that human capital in BMT has an average score of the overall indicator is 3.0. These findings indicate that human capital based on existing indicators is in moderate criteria. It means that individual capability, individual motivation, leadership, organizational climate, and workgroup effectiveness of human resources owned by BMT still need to get attention for improvement.

\section{Islamic Business Ethics}

The Islamic business ethics of BMT is judged on the basis of seven indicators which include mutual acceptance (taradhin), lawful (halalan thayyiban), no speculation (maysir), free manipulation (ghoror), and free usury, helping the weak and social responsibility. Based on the survey results, it is obtained a picture of the Islamic business ethics practice on BMT in Semarang that the average score of all indicators is 3.6, which shows the high criteria. This condition illustrates that the BMT in its operations has done its best to implement Islamic business ethics.

\section{Network Quality}

Network quality on BMT is assessed based on four indicators, namely; mutual help, mutual learning, commitment to grow together, and remind each other. Based on the survey 
results, it is obtained the average value of the overall indicator is equal to 2.8 which shows the quality of the network on the BMT in the context of mutual help, mutual learning, commitment to grow together, and remind each member of the Indonesian BMT Association in Semarang are in the medium criteria. It means, it has not yet been an ideal position, there still needs to be improvements to help each other, commitment to grow together, mutual learning, and remind each other.

\section{BMT Performance}

BMT performance is assessed based on six indicators, namely; profit growth, asset growth, member growth, nonperforming financing (NPF), zakat infaq sadaqah (ZIS) fund management, and social roles (Qardhul Hasan financing). Based on the survey results, it is obtained the average score of all indicators is 2.6. This shows the BMT performance in terms of profit growth, asset growth, member growth, NPF, ZIS fund management, and social role are in moderate criteria, meaning that it is not in an ideal position and still needs improvement, especially in ZIS management, because it has the lowest score. The findings indicate that BMT in ZIS still become side line, have not yet assigned specific employees to handle the Baitul Maal part.

\section{Regression Analysis Result}

By referencing to the regression model that has been formulated the previous section and the existing data, the estimated regression coefficient is as follows:

Table 1. Results of Regression Parameter Estimation

\begin{tabular}{cccccc}
\hline No & $\begin{array}{c}\text { Dependent } \\
\text { Variable }\end{array}$ & $\begin{array}{c}\text { Independent } \\
\text { Variable }\end{array}$ & $\begin{array}{c}\text { B Standard- } \\
\text { ized }\end{array}$ & t value & Sign \\
1 & BP-BMT & HC & .187 & 2.117 & $.042^{* *}$ \\
2 & BP-BMT & IBE & .190 & 2.188 & $.040^{* *}$
\end{tabular}


3 BP-BMT

$$
\begin{array}{llll}
\text { HCN NQ } & .235 & 2.491 & .025^{* *}
\end{array}
$$

BP-BMT

4

IBE*NQ

.680

$3.916 \quad .000^{*}$

5 F Value

$.000 *$

6 R Square

$$
=0.465
$$

7 DW

$$
=1.797
$$

Note: * significant at $a=1 \%$ and ** significant at $a=5 \%$

Based on Table 1 above, it can be explained that the test result of the effect of each variable on the BMT performance as follows:

\section{Effect of Human Capital on the BMT Performance}

The estimation results of regression coefficient of human capital is at 0.187 with a significance level of 0.042 (less than 0.05), the $\mathrm{H} 1$ which states that human capital positively affects the performance of BMT is accepted, it shows that human capital has a significant influence on BMT performance.

The results show that human capital has a significant positive effect on the BMT performance. It means that the better human capital will be able to improve the BMT performance. BMT with employees who are capable, have a high motivation to work, have good leadership, organizational climate as well as group work well, it will boost profit growth, market growth, declining non-performing financing, the better the management of zakat funds, infaq and sadaqah, and increased social role.

\section{Effect of Islamic Business Ethics on BMT Performance}

The estimation results of Islamic business ethics regression coefficients is at 0.190 with a significance level of 
0,040 (less than 0.05), then H2 which states that Islamic Business Ethics positive effect on the BMT performance is accepted, it shows that the Islamic business ethics has significantly positive effect on BMT performance. This result means that the better implementation of Islamic business ethics will be able to improve the BMT performance. BMT is emphasized on mutual willingly or blessing / without coercion ('an taradhin) in every transaction, committing the lawful and thayib, do not do speculation (maysir), not to manipulate (ghoror), does not practice usury, help the weak and social responsibility, it will be able to boost profit growth, market growth, declining nonperforming financing, improvements in the management of zakat, infaq and sadaqah, and increasing social role. Thus, it can be said that BMT Practicing Islamic business ethics seriously will be able to improve its performance.

\section{Network Quality Strengthens the Effect of Human Capital on the BMT Performance}

The regression coefficient results estimates moderating variable (the network quality of the human capital) amounted to 0.235 with a significance level of 0.025 (less than 0.05 ), H3 which states that the quality of the network can be able to moderate the influence of human capital on the BMT performance is accepted, it is indicated that the quality of the network variable is able to strengthen the influence of human capital on the BMT performance.

This result means that an organization (BMT) - a member of a network (i.e. linear network) - will have a better performance, this is because more information and cooperation among BMT (interaction with the network), BMT will be better able to develop human capital. The network will be able to push BMT to develop human capital better, and then it will have an impact on the development of BMT (on a more competitive level) and has better performance. This indicates that the quality of the network is able to strengthen the influence of human capital on the BMT performance. The regression coefficient (Beta Standardized) for human capital variable is equal to 0.187 and the regression coefficient of human capital that is moderated by the quality of the network showed larger numbers (i.e. 0.235). These 
results indicate that human capital variables are moderated by the quality of the network have the greater influence on the BMT performance improvement.

\section{Quality Network Strengthening the Influence of Islamic Business Ethics on the BMT Performance}

Regression coefficient results estimates moderating variables (quality of Islamic business ethics Network) amounted to 0.680 with a significance level of 0.000 (less than 0.05), H4 which states that the quality of the network of Islamic business ethics moderating influence on the BMT performance is accepted, it indicates that the quality of the network is able to moderate the influence of Islamic business ethics on the BMT performance.The results showed that the quality of the network is able to amplify the effect of Islamic business ethics implementation on the BMT performance. That means, the quality of the network is able to strengthen the BMT in applying Islamic business ethics which then affect the business BMT performance.The organizational network of BMT in practice could encourage its members to implement Islamic principles in its operations, so that BMT is not running the business narrowly that only maximize economic value, but it still considers the various issues related to the values of goodness and truth which is good and bad as well as considering what is halal and haram, humanizing and perform the steps in line with all stakeholders. An organizational network strengthens application of Islamic business ethics at BMT. If it is seen from the regression coefficient (Beta Standardized), it appears that the regression coefficients value for the Islamic business ethics variables at 0.190 and the regression coefficient of Islamic business ethics are moderated by the quality of the network showed larger numbers (i.e. 0.680). These results indicate that the Islamic business ethics which is reinforced by the quality of the network will have the greater influence on the BMT performance improvement.

In detail, the results showed that the influence of Islamic business ethics on the BMT performance is stronger than the effect of human capital as indicated by standardized regression coefficient of human capital variable $(=0.187)$ smaller than 
the coefficient regression Islamic business ethics $(=0.190)$. Overall results showed that the most dominant variable in determining the BMT performance is business ethics which is reinforced by the quality of the network that can be shown with standardized regression coefficients of the greatest (i.e. 0.680). Furthermore, the results of testing models of the effect of all the variables (together) on the BMT performance can be seen from the $\mathrm{F}$ value is equal to 8049 (at significance level of 0.000 ). This shows that all the observed variables, namely human capital, Islamic business ethics and quality of the network (as a moderating variable) have a positive effect on the BMT performance. This means that the model built can be used to predict the BMT performance improvement although there are many other variables that need to be incorporated into the model (remember the $\mathrm{R}$ square value is still relatively low at 0465).

\section{CONCLUSION AND POLICY IMPLICATION}

\section{Conclusion}

The existence of IMFI like BMT is expected to be able to help resolve the national issue namely eradicating poverty through micro-enterprise development. To be as expected, BMT required to having a good performance in achieving objectives. So, the efforts to improve the BMT performance are needed. Human capital, Islamic business ethics and the network is likely to have an important role in improving the BMT performance. Based on the discussions and analysis, it could be concluded as follows:

1. Human capital has a positive impact on the BMT performance, it indicates that the better human capital of BMT, it will encourage the BMT performance towards getting better, then to improve the BMT performance in the future need to continue to improve the quality of human capital.

2. Islamic business ethics also have a positive effect on the BMT performance. These results illustrate that the stronger implementation of Islamic business ethics will be able to improve the BMT performance. For those reasons, the strengthening of the Islamic business ethics implementation in BMT should continue to be emphasized. 
3. The quality of the network is able to strengthen the influence of human capital on the BMT performance. Coupled with improvements in the quality of the network, then the human capital is able to improve the better BMT performance.

4. The quality of the network is able to strengthen the influence of Islamic business ethics on the BMT performance. Accompanied by network quality, the better the Islamic business ethics, it will be able to improve the better BMT performance.

5. The figures above show that the BMT Network (Association) will have an important role in improving the BMT performance and the human capital quality and strengthening the implementation of Islamic business ethics.

\section{Policy implications}

Based on the research findings above, the policy is suggested to increase the BMT performance is as follows:

1. To improve performance, BMT need to strengthen human capital through enhanced capabilities such that through self-development of employees, by providing the greater opportunities for employees to develop skills and knowledge, for example by providing opportunities for education and training on a regular basis, provide an opportunity to continue education either with scholarships companies or their own expense. Besides that, it also needs to conduct activities that improve employee motivation, leadership training, conditioning organizational climate that supports employee development, and strengthen teamwork.

2. In an effort to improve performance, BMT need to strengthen implementation Islamic business ethics with an emphasis on the practice of mutual voluntary ( 'an taradhin) / no coercing in each transaction, develop good deeds and lawful (halalan thayyiban), do not do speculation (maysir), prevent individuals from acts of manipulation (ghoror), free from the practice of usury, develop a passion to help those who are weak, and to develop social awareness. In this case, the procurement of the Sharia Supervisory Board (SSB) for BMT is emphasized (for those who do not have a SSB) and increase the capacity 
and role of SSB for BMT that has SSB. Besides that, it also needs to continue to improve the understanding of Islamic business ethics in all employees of BMT.

3. Strengthen the network quality is required including through increased cooperation among BMT, increasing joint activities to increase knowledge and insight, increase joint commitment in developing the BMT, and increase to remind each other to implement Islamic values.

\section{Limitations and Future Research Agenda}

Research on the BMT performance is still confronted with the limitation that involves only three independent variables (human capital, Islamic business ethics and networking). It seems that further researches need to involve other variables with the consideration that the coefficient of determination in this study is still low (that is equal to 0.465), and many other variables that can be observed such as the factor of leadership and social capital. 


\section{References}

Al-Matari, E. M., Al-Swidi, A. K., \& Fadzil, F. H. B. (2014). The Measurements of Firm Performance's Dimensions. Asian Journal of Finance $\mathcal{E}$ Accounting, 6(1), 24 - 49. https:/ / doi. org/10.5296/ajfa.v6i1.4761

Eldine, A. (2009). Etika Bisnis Islam. Retrieved September 8, 2015, from www.uikbogor.ac.id,

Ferell., O.C., Fraedrich, J., Ferrel, L. (2015). Bussiness Ethics Ethical decision making and cases. Stanford, USA: Cengage Learning.

Ghandi, K. and Oseyomon, L. (2014), Ethical Theory and Practices. 2nd edition. United State of America (USA): Oxford University Press.

Hitta, M. A., \& Collins, J. D. (2007). Business ethics, strategic decision making, and firm performance. Business Horizons, 50(5), 353-357. https://doi.org/10.1016/j. bushor.2007.04.004.

Jaleleddine, Rejeb Ben; Slimene Nadia, and M. S. (2014). Ethical Performance of Islamic Banks: the Case of the Tunisian Banking "Zaytuna. Journal of Islamic Banking and Finance., 2(1), 107-122.

Jalil, A. (2010). Implementation Mechanism of Ethics in Business Organizations. International Business Research, Vol. 3 Issue $4 ; 1-11$.

Kalm, M. (2012). The Impact of Networking on Firm Performance. Evidence from Small and Medium-Sized Firms in Emerging Technology Areas. (ETLA - The Research Institute of the Finnish Economy Discussion Paper No. 1278).

Kaplan, R. S. \& D. P. N. (1996). Using The Balanced Scorecard as Strategic. Havard: Harvard Business School Press.

Kariv, D., Menzeis, .T.V., Brenner, G.A., Filion, L. . (2009). Transnasional Networking and Bussiness perfomance: 
Ethnic entrepreneurs in Canada. ". Entreprenuership $\mathcal{E}$ Regional Development, 21(3), 239 - 264.

Kayed, R. N. dan M. K. Hasan. (2010). Islamic entrepreneurship: a case study of Saudi Arabia. Journal of Developmental Entrepreneurship, 15(4), 379-413.

Kenneth, C.N. \& Chukwuma, E. (2015). Business Ethics And Corporate Performance In The Banking Industry: A Study Of Selected Banks In The South East, Nigeria, $3(10), 15-22$.

Krishna, A., Dangayach, G. S., \& Jainabc, R. (2011). Business Ethics: A Sustainability Approach. Procedia - Social and Behavioral Sciences, 25(December), 281-286. https://doi. org/10.1016/j.sbspro.2011.10.548

Marimuthu, M., Arokiasamy, L., Ismail, M. (2009). Human Capital Development And Its Impact On Firm Performance: Evidence From Developmental Economics. The Journal of International Social Research, 2(8), 265 - 272.

Martina D.P. A. Ongkorahardjo, Antonius Susanto, D. R. (2008). Analisis Pengaruh Human Capital Terhadap Kinerja Perusahaan (Studi Empiris pada Kantor Akuntan Publik di Indonesia). Jurnal Akuntansi Dan Keuangan, 10(1), 1121.

Mayo, A. (2000). The Role of Employee Development in The Growth of Intellectual Capital. Personal Review, 29(4), 521-533.

Muafi, Suwitho, Purwohandoko, I. S. (2017). Human capital in Islamic Bank and its effect on the improvement of healthy organization and employee performance. International Journal for Quality Research, 11(January 2017), 849-868. https:// doi.org/10.18421/IJQR11.04-08

Nawatmi, S. (2010). Etika bisnis dalam perspektif Islam. Fokus Ekonomi, 9(1), 50-58. 
Noruzi, M. R. (2011). A quick look on Islamic entrepreneurship," Interdisciplinary. Journal of Contemporary Research in Bussiness, Vol. 2 Issue 10; 478-485.

Nzuve, Stephen N.M; and Bundi, E. G. (2014). Human capital management practices and firms performance: A survey of commercial banks in Kenya. Journal of Economic Literature, 39(4), 1 - 13.

Olayemi, S. O. O. (2012). Human capital investment and industrial productivity in Nigeria. International Journal of Humanities and Social Science, 2(16), 298 - 307.

Pratono; Alusius Hari; dan Rosli Mahood; (2014). Social capital and firm performance. Asian Social Science., 10(19), 1-11.

Rafiki, A. K. M. A. K. dan I. B. (2014). Islamic human capital and firm performance. International Journal of Bussiness Management, 9(4), 173 - 181.

Ranjay. (n.d.). Organizational Networks. Retrieved September 8, 2015, from homepage.ntu.edu.tw/-khsu/network/ reading/orgnet.pdf

Rylková, Ž. (2015). Measurement of business performance in relation to competitors. Economics and Management, 7(2), 13-19. https://doi.org/10.12846/j.em.2015.02.02

Samad, S. (2013). Assessing the Contribution of Human Capital on Business Performance. International Journal of Trade, Economics and Finance.

Santos, J. B., \& Brito, L. A. L. (2012). Toward a subjective measurement model for firm performance. BAR-Brazilian Administration Review, 9(SPL. ISS), 95-117. https://doi. org/10.1590/S1807-76922012000500007

Su, H., Y. (2014). Business Ethics the Development of Intellectual Capital. Journal of Bussiness Ethics, 119, 87-98.

Sumiyanto, A. (2012). BMT Menuju Koperasi Modern. Yogyakarta: ISES Publising. 
Tessema, A. D. (2014). The Impact of Human Capital on company performance Case of the footwear Sector in Ethiopia. JBAS, 6(2), 76-102.

Urban, B., \& Kongo, M. (2015). The relevance of human capital to firm performance: A focus on the retail industry in Kinshasa, Democratic Republic of Congo. Acta Commercii, 15(1), 1-9. https://doi.org/10.4102/ac.v15i1.261

Widiyanto, W. (2012). BMT dan Pengembangan Usaha Mikro. Semarang: Unissula Press. 